\title{
Efficacy Of Enrofloxacin Against Transmissible Resistance Gene (Qnrs And Aac (6')-Ib-Cr) - Containing Escherichia Coli Isolates And Clones ${ }^{*}$ Murat CENGIZZ, Erdem ARSLAN
}

Laboratory of Molecular Pharmacology, Department of Pharmacology and Toxicology,Faculty of Veterinary Medicine, Uludag University, 16059, Nilufer, Bursa, Turkey

\author{
Received 06.02.2018 Accepted 22.02.2018
}

\begin{abstract}
Aim of this study was to investigate the effects of qnrS1 and aac (6')-Ib-cr on susceptibility, some pharmacodynamics of enrofloxacin against molecularly constructed and natural isolates of E. coli from animals. The MPCs and mutation frequencies of the drug were determined using the agar dilution method. Time-kill assays were used to determine the antimicrobial activity of the drug against E. coli strains. MPCs of enrofloxacin for qnrS1- and aac(6')-Ib-cr-containing transformants increased from $0.128 \mu \mathrm{g} / \mathrm{ml}$ to 2 and $4 \mu \mathrm{g} / \mathrm{ml}$. MPC:MIC ratio of enrofloxacin for transformants and E. coli isolates were 4 and 8 , respectively. Mutation frequencies were markedly higher for transformants and isolates compared to control strain. Mutation frequencies diminished up to $6.2 \mathrm{x} 10-18$ by increasing the concentrations used in the assay. The results of this study showed that enrofloxacin is less active against E. coli strains in case of additional mutations in QRDR. The concentration-dependent bactericidal effect of enrofloxacin is only observable by the eight times the MIC and increasing concentrations did not alter the bactericidal activity. The combination therapy can be considered to fight with resistant E. coli instead of monotherapy and artificially constructed E. coli strains, which exhibit similar reactions against ENR with natural E. coli isolates, can be used to test the pharmacological efficacy of the combinations.
\end{abstract}

Key words: E. coli, qnrS, aac(6')-Ib-cr, mutant prevention concentration, time-kill

\section{Introduction}

Due to their excellent in vitro activity, flouroquinolones (FQs) are commonly used in the treatment of animal infections worldwide. Enrofloxacin (ENR) is the first FQ which is approved for use in the treatment of animals. With the extensive consumption of FQs in human and veterinary medicine, dissemination of FQ-resistant Escherichia coli (E. coli) isolates has become a major problem in infection control and treatment in the last decade worldwide (Sukul and Spiteller, 2007).
FQs are synthetic antimicrobials displaying concentration depended bactericidal effect by inhibiting the bacterial topoisomerase enzymes. Mutations in the quinolone resistance-determining region (QRDR) resulting in structural alterations in target enzymes are an important mechanism of FQ resistance. Plasmid-mediated quinolone resistance (PMQR) genes also contribute to the resistance to FQs by either altering the molecular structure of FQ target enzymes or enzymatic inhibition of FQs. The first reported PMQR mechanism was the qnr gene, which encodes a protein that protects type II topoisomerases from quinolones (Martinez-Martinez et al., 1998). The aac (6')-Ib-cr

* Corresponding author: Adres: Uludağ Üniversitesi Veteriner Fakültesi Farmakoloji ve Toksikoloji Anabilim Dalı, Görükle Kampusu, 16059, Bursa, Türkiye. E-mail: cengizm@uludag.edu.tr Telephone: +902242941323 Fax: +902242941202 
gene is one of the major PMQR genes and is a variant of aac (6')-Ib which has two codon changes (Trp-102 $\rightarrow$ Arg and Asp-179 $\rightarrow$ Tyr). The aac (6')-Ib-cr gene encodes aminoglycoside acetyltransferase enzyme which is capable of modifying some FQs and reducing their activity via acetylation.

QRDR mutations and PMQR genes have been widely reported worldwide (Ferreira et al., 2010; Fortini et al., 2010; Akiyama and Khan, 2012). Cengiz et al. (2013) demonstrated a difference on the bactericidal activity of ENR against gyrA mutants and qnr-containing E. coli isolates even at the identical MICs. This suggests that genetic variations may have different effects on pharmacological activity of antimicrobials and survival of resistant sub-populations. Therefore, aims of this study was to investigate the effects of transmissible quinolone resistance genes (aac (6')-Ib-cr and qnrS1) on susceptibility, mutant prevention concentration (MPC), mutation frequency (MF) and efficacy of bactericidal activity of ENR against molecularly constructed and natural isolates of $\mathrm{E}$. coli harbouring various $\mathrm{QRDR}$ mutations and $\mathrm{PMQR}$ genes.

\section{Materials and Methods}

\section{Bacterial strains}

Previously characterized five E. coli isolates collected from animals (Dalhoff and Schimitz, 2003), three transformants and one control strain (E. coli ATCC 25922) were used in this study.

Molecular cloning

Cloning of aac (6 $\left.6^{\prime}\right)-\mathrm{Ib}-\mathrm{cr}$ and $\mathrm{qnrS} 1$ genes were performed as previously described by Emrich et al. (2010). qnrS1 gene was PCR amplified using primer pairs qnrs1 (F- ATACAAGCTTGATGGAAACCTACAATCATACA, R- ATACAAGCTTTTAGTCAGGATAAACAACAAT), the resulting PCR product was digested with HindIII and ligated to the specific HindIII site of pUC19.

Cloning of aac $\left(6^{\prime}\right)-\mathrm{Ib}$-cr gene was performed in a twostep procedure. In the first step, aac $\left(6^{\prime}\right)-\mathrm{Ib}-\mathrm{cr}$ gene was PCR amplified using primers aac(6')-Ib-cr2 (F- ATACAAGCTTGACAAAGTTAGGCATCACAAAGT, R- ACTATAAGCTTTTAGGCATCACTGCGTGTTC). Then the resulting DNA fragment was digested with HindIII and inserted into specific HindIII site of pUC19 with using T4 DNA Ligase. In the second step, the resulting recombinant plasmid was used as template for a second PCR amplification using primer pairs of aac(6')-Ib-cr $\Delta$ lacZ (F-CTTTGTGATGCCTAACTTTGTTTTTGCGTTGCTCATAGCTGTTTCCTGTGTGAAATTG, R-ACAAAGTTAGGCATCACAAAGTACAGCATCGTGACCAACAGC). Verified PCR fragment then used directly for transformation of the respective E. coli recipient strains (E. coli ATCC 25922) that were called as MtX for aac(6')-Ib-cr and MtS for qnrS1. Transformation was performed by using Transform Aid Bacterial Transformation Kit (Fermentas), as described by the manufacturer. Transformants were selected on $50 \mu \mathrm{g} / \mathrm{ml}$ ampicillin containing Luria-Bertani (LB) agar plates.

Mutant prevention concentration and mutation frequency The MPC of ENR was determined by the method of Blondeau et al. (2009). Briefly, each E. coli isolate and control strain was freshly grown from stock stored at -25 ${ }^{\circ} \mathrm{C}$. Strains were incubated overnight at $37^{\circ} \mathrm{C}$ in $100 \mathrm{ml}$ of Mueller-Hinton Broth (MHB). Cultures were centrifuged at $9000 \mathrm{rpm}$ for 20 minutes. The supernatant was discarded and pellet was re-suspended in $3 \mathrm{ml}$ of MHB to reach > $1010 \mathrm{cfu} / \mathrm{ml}$. A $100 \mu \mathrm{l}$ of this culture was used to inoculate Plate Count Agar (PCA) plates containing 1xMIC-32xMIC range of ENR. The plates were examined every 24 hours for growth of E. coli. The MPC was determined as the concentration that allowed no growth of bacteria at the end of 96 hours incubation.

MFs were determined by the method of Ricci et al. (2006). The parent strains grown overnight in antibiotic-free broth were concentrated by centrifugation and resuspended in sterile broth to give a range of inocula (106 to $1010 \mathrm{cfu} /$ $\mathrm{ml})$. Agar plates containing ENR at 0.5, 1, 2 and 4 times the MIC were inoculated with $100 \mu \mathrm{l}$ (105 to $109 \mathrm{CFU}$ ) of each cell suspension and incubated at $37^{\circ} \mathrm{C}$ for up to $96 \mathrm{~h}$.

Time-kill assay

Time-kill experiments were performed as described by Begic et al. (2009). A liquid overnight bacterial culture of bacterial strains was diluted with MHB. The following ENR concentrations were tested: $0,0.5,1,2,4,8,16$ and 32 times the MIC. Bactericidal activity was defined as a $\geq 3 \log$ decrease in $\mathrm{cfu} / \mathrm{ml}$ relative to the bacterial concentration at $0 \mathrm{~min}$.

\section{Results}

In the present study, the transfer of transmissible genes to reference strain increased the MICs of ENR against mo- 
Table 1. Resistance profiles and mechanisms of E. coli, mutant prevention concentrations of enrofloxacin and mutant frequencies of the strains and time-kill assays

\begin{tabular}{|c|c|c|c|c|c|c|c|c|c|}
\hline \multirow{2}{*}{ E. coli strain } & \multirow{2}{*}{ Genotype } & \multirow{2}{*}{$\begin{array}{l}\mathrm{MIC}_{\mathrm{ENR}} \\
(\mu \mathrm{g} / \mathrm{ml})\end{array}$} & \multirow{2}{*}{$\begin{array}{l}\mathrm{MPC}_{\mathrm{ENR}} \\
(\mu \mathrm{g} / \mathrm{ml})\end{array}$} & \multicolumn{4}{|c|}{ Mutation frequency (cfu/ml) } & \multicolumn{2}{|c|}{ Time-kill (conc/log reduction) } \\
\hline & & & & $0.5 \mathrm{xMIC}$ & $1 \mathrm{xMIC}$ & $2 \mathrm{xMIC}$ & $4 \mathrm{xMIC}$ & $8 \mathrm{~h}$ & $24 \mathrm{~h}$ \\
\hline ATCC25922 & - & 0.032 & 0.128 & $4.8 \times 10^{-10}$ & $5.1 \times 10^{-16}$ & $5.2 \times 10^{-18}$ & - & $\begin{array}{l}8 \mathrm{xMIC} / 3 \log _{10} \\
16 \mathrm{xMIC} \geq 4 \log _{10}\end{array}$ & $\begin{array}{l}\mathrm{MIC} / 3 \log _{10} \\
2 \mathrm{xMIC} / \geq 4 \log _{10} \\
4 \mathrm{xMIC} / \geq 5 \log _{10} \\
8 \mathrm{xMIC} \geq 6 \log _{10}\end{array}$ \\
\hline $\mathrm{MtS}$ & qnnSI & 0.512 & 2 & $4.4 \times 10^{-8}$ & $3.8 \times 10^{-10}$ & $5.2 \times 10^{-14}$ & - & $\begin{array}{l}4 \times \mathrm{xMIC} \geq 3 \log _{10} \\
8 \mathrm{xMIC} / \geq 4 \log _{10} \\
32 \mathrm{xMIC} / \geq 5 \log _{10} \\
\end{array}$ & $\begin{array}{l}2 x M I C / \geq 3 \log _{10} \\
4 x M I C / \geq 4 \log _{10} \\
8 x M I C / \geq 6 \log _{10}\end{array}$ \\
\hline $\mathrm{MtX}$ & $a a c\left(6^{\prime}\right)-I b-c r$ & 1 & 4 & $4.3 \times 10^{-9}$ & $5.5 \times 10^{-11}$ & $4.9 \times 10^{-14}$ & - & $\begin{array}{l}4 \mathrm{xMIC} \geq 3 \log _{10} \\
8 \mathrm{xMIC} / \geq 4 \log _{10}\end{array}$ & $\begin{array}{l}\mathrm{MIC} / \geq 3 \log _{10} \\
4 \mathrm{xMIC} / \geq 4 \log _{10} \\
8 \mathrm{xMIC} / \geq 5 \log _{10}\end{array}$ \\
\hline MtSX & $\begin{array}{l}q n r S 1 \\
a a c\left(6^{\prime}\right)-I b-c r\end{array}$ & 1 & 4 & $2.3 \times 10^{-8}$ & $4.2 \times 10^{-12}$ & $3.1 \times 10^{-13}$ & - & $\begin{array}{l}4 x M I C / \geq 3 \log _{10} \\
8 x M I C / \geq 4 \log _{10}\end{array}$ & $\begin{array}{l}2 x M I C / \geq 3 \log _{10} \\
4 x M I C / \geq 4 \log _{10} \\
8 x M I C / \geq 5 \log _{10}\end{array}$ \\
\hline E101 & $\begin{array}{l}q n r A l \\
a a c\left(\sigma^{\prime}\right)-I b-c r\end{array}$ & 32 & 256 & $4.1 \times 10^{-10}$ & $6.1 \times 10^{-12}$ & $2.4 \times 10^{-14}$ & $6.0 \times 10^{-15}$ & $\begin{array}{l}2 \mathrm{xMIC} / \geq 3 \log _{10} \\
8 \mathrm{xMIC} / \geq 4 \log _{10} \\
16 \mathrm{xMIC} / \geq 5 \log _{10}\end{array}$ & $\begin{array}{l}\mathrm{MIC} / \geq 3 \log _{10} \\
4 \mathrm{xMIC} / \geq 4 \log _{10} \\
16 \mathrm{xMIC} / \geq 5 \log _{10} \\
32 \mathrm{xMIC} / \geq 6 \log _{10}\end{array}$ \\
\hline E103 & $\begin{array}{l}q n r S 1 \\
a a c\left(6^{\prime}\right)-I b-c r\end{array}$ & 128 & 1024 & $6.3 \times 10^{-9}$ & $7.8 \times 10^{-12}$ & $4.9 \times 10^{-16}$ & $1.2 \times 10^{-18}$ & $\begin{array}{l}8 \mathrm{xMIC} / \geq 4 \log _{10} \\
16 \mathrm{xMIC} \geq 5 \log _{10}\end{array}$ & $\begin{array}{l}\mathrm{MIC} / \geq 3 \log _{10} \\
4 \mathrm{xMIC} / \geq 4 \log _{10} \\
16 \mathrm{xMIC} / \geq 5 \log _{10} \\
32 \mathrm{xMIC} / \geq 6 \log _{10}\end{array}$ \\
\hline E247 & $\begin{array}{l}\text { qnrSl } \\
\text { oqxB } \\
\operatorname{gyrA}(\mathrm{S} 83 \mathrm{~L}, \mathrm{D} 87 \mathrm{Y}) \\
\operatorname{parC}(\mathrm{S} 80 \mathrm{I})\end{array}$ & 128 & 1024 & $4.1 \times 10^{-12}$ & $6.1 \times 10^{-15}$ & $3.9 \times 10^{-17}$ & $5.9 \times 10^{-18}$ & $\begin{array}{l}4 \mathrm{xMIC} / 3 \log _{10} \\
8 \mathrm{xMIC} \geq 4 \log _{10} \\
16 \mathrm{xMIC} / \geq 5 \log _{10}\end{array}$ & $\begin{array}{l}\mathrm{MIC} / \geq 3 \log _{10} \\
4 \mathrm{xMIC} / \geq 4 \log _{10} \\
16 \mathrm{xMIC} / \geq 6 \log _{10}\end{array}$ \\
\hline E248 & qnrSl & 1 & 8 & $8.1 \times 10^{-8}$ & $4.0 \times 10^{-13}$ & $6.6 \times 10^{-15}$ & $2.4 \times 10^{-16}$ & $\begin{array}{l}4 \mathrm{xMIC} / \geq 3 \log _{10} \\
8 \mathrm{xMIC} / \geq 4 \log _{10} \\
32 \mathrm{xMIC} / \geq 5 \log _{10}\end{array}$ & $\begin{array}{l}\mathrm{MIC} / \geq 3 \log _{10} \\
4 \mathrm{xMIC} / \geq 4 \log _{10} \\
8 \mathrm{xMIC} / \geq 5 \log _{10}\end{array}$ \\
\hline E308 & $\begin{array}{l}\text { qnrSl } \\
\operatorname{grr}(\mathrm{S} 83 \mathrm{~L}, \mathrm{D} 87 \mathrm{~N}) \\
\operatorname{par} C(\mathrm{~S} 80 \mathrm{I}) \\
\operatorname{par} E(\mathrm{~S} 458 \mathrm{~A})\end{array}$ & 128 & 1024 & $3.3 \times 10^{-8}$ & $7.2 \times 10^{-11}$ & $5.7 \times 10^{-14}$ & $6.2 \times 10^{-18}$ & $8 \mathrm{xMIC} / \geq 4 \log _{10}$ & $\begin{array}{l}\mathrm{MIC} / \geq 3 \log _{10} \\
4 \mathrm{xMIC} / \geq 4 \log _{10} \\
8 \mathrm{xMIC} / \geq 5 \log _{10}\end{array}$ \\
\hline
\end{tabular}

lecularly constructed E. coli strains (table 1). Individually, qnrS1 and aac(6')-Ib-cr caused 16 and 32-fold an increase in the MICs of ENR, respectively. Coexistence of the genes increased the MIC of ENR from $0.032 \mu \mathrm{g} / \mathrm{ml}$ to $1 \mu \mathrm{g} /$ $\mathrm{ml}$ (32-fold). MPCs of ENR ranged from 4 to 8 times the MIC and MPCs for E. coli isolates were markedly higher than MPCs for transformants and control stain (table 1). Transmissible genes (qnrS1, aac (6 $\left.6^{\prime}\right)$-Ib-cr) elevated MPCs of ENR from $0.128 \mu \mathrm{g} / \mathrm{ml}$ to 2 and $4 \mu \mathrm{g} / \mathrm{ml}$ for the transformants (16 and 32-fold). For some E. coli isolates (E103, E247, E308), MPCs of ENR were 8000 times the MPC for control strain.

The results of time-kill assays were presented in table 1 . In time-kill assays, ENR did not achieve total bacterial elimination ( $\geq 6 \log$ ) within 8 hours and ENR concentrations required for bacterial elimination within 24 hours were lower than those for 8 hours. $\geq 5 \log$ reduction against qnrS-containing MtS and E. coli E248 was achieved at maximum concentration used in the assays (32xMIC). However, ENR achieved total bacterial elimination only for MtS among transformants in 24 hours at 0.25 times the concentration used in 8 hours. An increase in bactericid- al activity of ENR against transformants did not occur in 24 hours at all concentrations over $\geq 8$ times the MIC. The same concentrations of ENR ( 8 times MIC) caused $\geq 4 \log$ reduction against $\mathrm{qnrS}+\mathrm{aac}\left(6^{\prime}\right)$-Ib-cr-containing MtSX and E. coli E103. Although, MtSX was inhibited 1 log less than E. coli E103 in the end of time-kill assay. QRDR mutations caused $1 \log$ decrease in the inhibition of E. coli isolates (E247, E308) compared to MtS.

Table 1.

\section{Discussion and Conclusion}

PMQR genes confer low-level quinolone resistance (Strahilevitz et al., 2009). Transfer of qnr genes increases the MICs of FQs up to 125-fold according to the previous studies (Oloffson et al., 2007; Fortini et al., 2011). Whereas, aac(6')Ib-cr gene has lower potential than qur genes to increase MICs of FQs (Dalhoff and Schimitz 2003; Robicsek et al., 2006; Strahilevitz et al., 2009; Emrich et al., 2010; Brailes et al., 2011; Chodhury et al., 2011). The results of this study showed that transfer of qnrS1 and aac $\left(6^{\prime}\right)-\mathrm{Ib}-\mathrm{cr}$ genes to $\mathrm{E}$. coli reference strain caused 16 and 32 -fold an increase in 
the MICs of ENR, respectively.

MPC testing is technically more demanding than MIC testing (1010cfu/ml versus $105 \mathrm{cfu} / \mathrm{ml}$ respectively) and may also offer some value for guiding optimal antimicrobial therapy as it provides practical information on drug concentrations necessary to restrict mutant growth (Dalhoff and Schimitz, 2003). MPC:MIC ratio of FQs vary depending on bacterial strain and its genotype and may reach up to 136 according to the previous studies (Randall et al., 2004; Wetzein, 2005; Oloffson et al., 2007). The results of this study showed that MPC:MIC ratio of ENR for transformants and E. coli isolates were 4 and 8, respectively. MPC:MIC ratio of ENR reached up 32-fold for qnrS+aac(6')-Ib-cr-containing MtSX and 8000-fold for E. coli isolates compared to the control strain. Briales et al. (2011) reported that MPC:MIC ratio of FQ may increase up to 4000-16000 in the presence of QRDR mutations and PMQR genes in an E. coli strain. Mutation frequencies ranged from 5.1x10-16 to $3.8 \times 10-10$ at $1 \times$ MIC and were markedly higher for transformants and isolates compared to control strain. Mutation frequencies diminished up to $6.2 \times 10-18$ by increasing the concentrations used in the assay. Sub-MIC concentrations of FQs increase mutation frequencies in E. coli (Ozawa and Asai, 2013). In this study, transformants and E. coli isolates had markedly higher mutation frequencies than control strain at $1 \mathrm{xMICs}$. This result supported that transmissible resistance genes increase the mutation possibility when MICs are used for the inhibition of bacteria. Brailes et al. (2011) also stated that the PMQR might enable mutant bacteria with low levels of FQ resistance to survive long enough for them to grow and emerge during FQ treatment. qnrS1-containing MtS had highest mutation frequency at $1 x M I C s$. There is no significant difference between mutation frequencies of qnrS+aac(6')-Ib-cr-containing MtSX and qnrS+aac(6')-Ib-cr-containing E. coli E103 ( x10-12). In this study, mutation frequencies decreased from $3.3 \times 10$ 8 up to $6.2 \times 10-18$ in higher concentrations than MICs as reported previously (Kim et al, 2003; Drago et al., 2010).

In veterinary medicine ENR is administered by subcutaneous injection to cattle and intramuscular injection to pigs and orally to cattle, pigs turkeys and chickens, for the treatment of infections of respiratory and alimentary tract. The recommended doses are 2.5 to $5 \mathrm{mg} / \mathrm{kg}$ bw/day for 3 to 5 days (cattle and pigs) or $10 \mathrm{mg} / \mathrm{kg}$ bw/day for 3 to 10 days (chickens and turkeys) (EMA, 1998a). Cmax values of 0.45$2.7 \mu \mathrm{g} / \mathrm{ml}$ were attained 1 to 2 hours after administration
(EMA, 1998b). E. coli is a sensitive species given MIC values of $0.03 \mu \mathrm{g} / \mathrm{ml}$ against ENR (EMA, 1998a). Based on the results of this study, bactericidal activity of ENR can shortly be observed after administration against transmissible resistance gene-containing transformants and qnrS1-containing E. coli E248, but daily recommended doses (2.5-10 $\mathrm{mg} / \mathrm{kg}$ bw/day) of ENR may not be caused desired inhibition after 8 and 24 hours of administration and mutation tendency of E. coli may increase. Jacobsen et al. (2012) reported that the cfu counts for isogenic qnrS-containing E. coli incubated in 4xMIC reduced during 5-24 hours and the cfu counts for 8-16xMIC remained stable during hours 5-24. In this study, $1 \log$ reduction addition to the reduction recorded in 8 hours was observed in 24 hours. Bacterial inhibition remained stable only for qnrS1-containing E. coli E248.

In conclusion, mutation frequencies of E. coli strains reduced by the increasing of ENR concentrations. In the other hand, ENR is less active against E. coli strains in case of additional mutations in QRDR. The concentration-dependent bactericidal effect of ENR is only observable by the eight times the MIC and increasing concentrations did not alter the bactericidal activity. Therefore, dose optimization approach is not efficient to gain back the bactericidal activity of ENR which is one of the commonly used FQ in veterinary medicine. The combination therapy can be considered to fight with resistant E. coli instead of monotherapy and artificially constructed E. coli strains, which exhibit similar reactions against ENR with natural E. coli isolates, can be used to test the pharmacological efficacy of the combinations.

\section{Acknowledgement}

This study was financed by the Research Fund of Uludag University [KUAP-2015/10].

\section{References}

Akiyama T, Khan AA. Molecular characterization of strains of fluoroquinolone resistant Salmonella entericaserovar Schwarzengrund carrying multidrug resistance isolated from imported foods. J Antimicrob Chemother, 67:101-110, 2012.

Begic D, Von Eiff C, Tsuji BT. Daptomycin pharmacodynamics against Staphylococcus aureus hemB mutants displaying the small colony vari- 
ant phenotype. J Antimicrob Chemother, 63:977-981, 2009.

Blondeau JM. New concepts in antimicrobial susceptibility testing: the mutant prevention concentration and mutant selection window approach. Vet Dermatol, 20:383-396, 2009.

Briales A, Rodriguez-Martinez JM, Velasco C, Diaz De Alba P, Dominquez-Herrera J, Pachon J, Pascual A. In vitro effect of qnrA1, qnrB1, and qnrS1 genes on fluoroquinolone activity against isogenic Escherichia coli isolates with mutations gyrA and parC. Antimicrob Agents Chemother, 55:1266-1269, 2011.

Cengiz M, Sahinturk P, Sonal S, Buyukcangaz E, Sen A, Arslan E. In vitro bactericidal activity of enrofloxacin against gyrA mutant and qnr-containing Escherichia coli isolates from animals. Vet Rec, 172(18):474, 2013.

Chodhury G, Pazhani GP, Nair GB, Ghosh A, Rammurthy T. Transferable plasmid-mediated quinolone resistance in association with extended spectrum $\beta$-lactamases and fluoroquinolone-acetylating aminoglycoside-6-N acetyltransferase in clinical isolates of Vibrio fluvialis. Int J Antimicrob Agents, 38:169-173, 2011.

Dalhoff A, Schimitz FJ. In vitro antibacterial activity and pharmacodynamics of new quinolones. Eur J Clin Microbiol Infect Dis, 22:203-221, 2003.

Drago L, Nicola L, Mattina R, De Vecchi E. In vitro selection of resistance in Escherichia coli and Klebsiellaspp. at in vivo fluoroquinolone concentrations. BMC Microbiol, 10:119, 2010.

Emrich NC, Heisig A, Stubbings W, Labischinski H, Heisig P. Antibacterial activity of finafloxacin under different $\mathrm{pH}$ conditions against isogenic strains of Escherichia coli expressing combinations of defined mechanisms of fluoroquinolone resistance. J Antimicrob Chemother, 65:2530-2533, 2010

European Medicines Agency (EMA) Committee for Veterinary Medicinal Products. Enrofloxacin (modifications for bovine, porcine and poultry) Summary Report (2), EMEA/MRL/388/98a, 1998a.

European Medicines Agency (EMA) Committee for Veterinary Medicinal Products. Enrofloxacin (extension to sheep, rabbits and lactating cows) Summary Report (3), EMEA/MRL/389/98b, 1998b.

Ferreira S, Toleman M, Ramalheira E, Da Silva GJ, Walsh T, Mendo S. First description of Klebsiella pneumoniae clinical isolates carrying both qnrA and qnrB genes in Portugal. Int J Antimicrob Agents, 35:584$586,2010$.
Fortini D, Fashae K, Garcia-Fernandez A, Villa L, Carattoli A. Plasmid-mediated quinolone resistance and $\beta$-lactamases in Escherichia coli from healthy animals from Nigeria. J Antimicrob Chemother, 66:1269-1272, 2011.

Jacobsen L, Cattoir V, Jensen KS, Hammerum AM, Nordman P, Frimondt-Moller N. Impact of low-level fluoroquinolone resistance genes qnrA1, qnrB19 and qnrS1 on ciprofloxacin treatment of isogenic Escherichia coli strains in a murine urinary track infection model. J Antimicrob Chemother, 67:2438-2444, 2012.

Kim MJ, Yun HJ, Kang JW, Kim S, Kwak JH, Choi EC. In vitro development of resistance to a novel fluoroquinolone, DW286, in methicillin-resistant Staphylococcus aureus clinical isolates. J Antimicrob Chemother, 51:1011-1016, 2003.

Martinez-Martinez L, Pascual A, Jacoby G. Quinolone resistance from a transferable plasmid. Lancet, 351:797-799, 1998.

Oloffson SK, Marcusson LL, Stormback A, Hughes D, Cars O. Dose-related selection of fluoroquinolone-resistant Escherichia coli. J Antimicrob Chemother, 60:795-801, 2007.

Ozawa M, Asai T. Relationships between mutant prevention concentrations and mutation frequencies against enrofloxacin for avian pathogenic Escherichia coli isolates. J Vet Med Sci, 75(6):709-713, 2013.

Randall LP, Cooles SW, Piddock LJV, Woodward MJ. Mutant prevention concentrations of ciprofloxacin and enrofloxacin for Salmonella enterica. J Antimicrob Chemother, 54:688-691, 2004.

Ricci V, Tzakas P, Buckley A, Piddock LJ. Ciprofloxacin-resistant Salmonella enterica serovar Typhimurium strains are difficult to select in the absence of AcrB and TolC. Antimicrob Agents Chemother, 50(1):38-42, 2006.

Robicsek A, Jacoby GA, Hooper DC. The worldwide emergence of plasmid-mediated quinolone resistance. Lancet Infect Dis, 6:629-640, 2006.

Sahinturk P, Arslan E, Buyukcangaz E, Sonal S, Sen A, Ersoy F, Piddock LJV, Webber M, Cengiz M. High level fluoroquinolone resistance in Escherichia coli isolated from animals in Turkey is due to multiple mechanisms. Turk J Vet Anim Sci, 40:214-218, 2016.

Strahilevitz J, Jacoby GA, Hooper DC, Robicsek A. Plasmid-mediated quinolone resistance: a multifaceted threat. Clin Microbiol Rev, 22(4):664-689, 2009.

Sukul P, Spiteller M. Fluoroquinolone antibiotics in the environment. 
Rev Environ Contam Toxicol, 191:131-162, 2007.

Wang M, Sham DF, Jacoby GA, Hooper DC. Emerging plasmid-mediated quinolone resistance associated with the qnr gene in Klebsiella pneumoniae clinical isolates in the United States. Antimicrob Agents Chemother, 48(4):295-1299, 2004.

Wang M, Tran JH, Jacoby GA, Zhang Y, Wang F, Hooper DC. Plasmid-mediated quinolone resistance in clinical isolates of Escherichia coli from Shanghai, China. Antimicrob Agents Chemother, 47(7):22422248, 2003.

Wetzein HG. Comparative mutant prevention concentrations of pradofloxacin and other veterinary fluoroquinolones indicate differing potentials in preventing selection of resistance. Antimicrob Agents Chemother, 49(10):4166-41, 2005. 